\title{
Description of Clean and Healthy Living Behavior (PHBS) With Hand Washing With Soap During The Covid-19 Pandemic in South Tangerang City in 2021
}

\author{
${ }^{1}$ Ghina Syania Zahirah, ${ }^{2}$ Hilda Mutiah, ${ }^{3}$ Klarysa, ${ }^{4}$ Mutiara Ramadhani Putri, ${ }^{5}$ Munaya Fauziah \\ $1,2,3,4,5$ Faculty of Public Health, Muhammadiyah University of Jakarta \\ K.H. Ahmad Dahlan St, Cireundeu, Ciputat, South Jakarta, 15419 \\ E-mail: ghinasyania@gmail.com
}

\begin{abstract}
The South Tangerang Health Office noted that there were 285 new cases of Covid 19 in April. The addition of positive cases in South Tangerang is the second-highest since the Covid-19 pandemic hit in March 2020. Based on several studies in the southern Tangerang city area, there is still a lack of knowledge, attitudes, and behavior in washing hands with soap. The purpose of this study was to determine the description of healthy and healthy behavior (PHBS) by washing hands with soap during the covid-19 pandemic in the city of South Tangerang. The type of research used is qualitative research. The statements of the four informants regarding their knowledge, attitudes, and behavior regarding handwashing with soap during this pandemic are quite good. Washing hands with soap during this pandemic is very important. According to the results of research on members of each researcher in South Tangerang City, washing hands with soap during the pandemic has considered very important.
\end{abstract}

Keywords: Clean and Healthy Behavior (PHBS), Washing Hands with Soap, Covid-19 


\section{INTRODUCTION}

The Covid-19 pandemic has been going on for about a year. This virus can spread through the air. The viral Covid-19 caused by severe acute respiratory syndrome-corona virus-2 (SARS-CoV2) has caused panic all over the world, including in Indonesia. Even though the WHO, the Centers for Disease Control and Prevention (CDC), and the Indonesian Ministry of Health have issued a lot of actual information and guides related to Covid19, there is still confusion and confusion about the news that is not valid. Even though the transmission of this virus can be prevented by implementing a Clean and Healthy Lifestyle (PHBS), one of which is by washing hands with soap (Tabi'in, 2020 in Hardiningrum, Hakim, 2021).

Handwashing with soap is a process that mechanically removes dirt and debris from the skin of the hands by using soap (either containing antimicrobial or non-antimicrobial) and water. Washing hands with soap is an easy, cheap, and simple healthy behavior that can scientifically prevent the spread of infectious diseases (Mawarni, 2013).

Washing your hands frequently and appropriately (for at least 40 seconds) is one of the most important steps to prevent COVID-19 infection. CTPS is much more effective at killing germs, bacteria, and viruses than washing hands with water alone. Soap can easily destroy the lipid membrane of COVID-19, making the COVID-19 virus inactive (Kemenkes RI, 2020)

The results of the Indonesian Demographic and Health Survey (2017) show that 93\% of Indonesians are accustomed to washing their hands using soap and running water. The rest of the Indonesian people wash their hands using only water and cleaning detergent, and wash their hands with soap without using water. This shows that the Indonesian people already have a good habit of washing their hands using soap and running water. It's just that when this pandemic situation occurs the intensity is increased (Kompas: April 10, 2020, in Hardiningrum, Hakim, 2021).

Based on data reported from infocorona.bantenprov.go.id, with the additional cases, the cumulative case findings reached 55,384 cases, with details, 4,101 patients were still being treated, 50,763 patients recovered and 1,430 people died. While the additional details from the regencies/cities are, Pandeglang Regency 55 cases, Tangerang Regency 107 cases, Tangerang City 183 cases, South Tangerang City (Tangsel) 77 cases, Serang City 26 cases, Cilegon City 134 cases, Lebak Regency 231 cases. Of the eight regencies/cities, only Serang Regency did not contribute to the increase in Covid19 cases, aka zero cases.

South Tangerang Health Office noted, there were 285 new cases of Covid-19 in April. The addition of positive cases in Tangsel is the second-highest since the Covid-19 pandemic hit in March 2020. On January 25, 2021, Tangsel recorded daily addition of positive cases The highest number of Covid-19 cases was 291 . With yesterday's addition, the total Covid-19 cases which were recorded by the South Tangerang Health Service has been as many as 12,854 cases. Of these, Covid-19 Handling 
Task Force confirms 11,282 of whom have recovered or increased by 30 people from the last data on Saturday (Kompas.com).

Hand washing can be influenced by several factors including knowledge and attitudes (Behavior Notoatmodjo, 2010 in W Wahyuni, 2020). Knowledge is the output of sensory processes, especially the eyes and ears on a particular object. Attitude is a person's closed response to an object or stimulus that comes from within or from outside and its manifestation cannot be seen directly, but can only be interpreted by the closed behavior (Sunaryo, 2014 in W Wahyuni, 2020). Knowledge and attitudes towards handwashing can influence a person to be willing and able to carry out handwashing behavior.

Research on the knowledge, attitudes and behavior of Handwashing with Soap on FKIK students UIN Syarif Hidayatullah Jakarta 2015 conducted by Irma Sari Muliadi reported that from 100 respondents, 58\% of respondents had good knowledge about Handwashing with Soap, 99\% of respondents had good attitudes about Washing Hands with Soap, and 67\% of respondents have good behavior regarding Hand Washing with Soap (Muliadi \& Sari, 2015). Furthermore, research conducted by Haryani, et al (2021) on the knowledge and behavior of washing hands in SMK students as an effort to prevent COVID-19 showed that $75 \%$ or 90 SMK students had good knowledge, $85.8 \%$ or 103 SMK students behaved well. Statistically, the results of the analysis illustrate that there is a relationship with CTPS and it is recommended to increase prevention efforts against COVID-19 with 3M, namely washing hands with soap, wearing masks, and maintaining distance (Haryani, 2021).

\section{METHODS}

The research used is qualitative research using participatory observational methods, where this research was conducted by interviewing 4 sources of informants in-depth (in-depth interviews).

\section{RESULTS AND DISCUSSIONS}

Participation or through communication media between interviewers and informants, with or without using interview guidelines. Interviews conducted by researchers took approximately 20-30 minutes.

Based on the content analysis table below, the four informants regarding the behavior of washing hands with soap are classified as good, where all four informants have washed their hands with soap during the Covid-19 pandemic. For the frequency of washing hands per day during the pandemic, based on the answers of the four respondents, all of them answered that they often washed their hands with soap ring the Covid-19 pandemic. 
Table 1. Content Analysis

\begin{tabular}{|c|c|c|c|c|c|}
\hline Topic & Meaning Unit & Code & $\begin{array}{c}\text { Sub } \\
\text { category }\end{array}$ & Category & Theme \\
\hline $\begin{array}{l}\text { 1. Brothers and } \\
\text { sisters please tell me } \\
\text { since During the } \\
\text { Covid-19 pandemic, } \\
\text { did you wash your } \\
\text { hands with soap? }\end{array}$ & $\begin{array}{l}\text {-Wash your hands } \\
\text { frequently during the } \\
\text { covid-19 pandemic - } \\
\text { Yes, wash your hands } \\
\text { every day but the } \\
\text { uncertain }\end{array}$ & often do & Diligent & $\begin{array}{l}\text { Behavior of } \\
\text { CTPS }\end{array}$ & CTPS \\
\hline $\begin{array}{l}\text { a. If yes, how } \\
\text { many times a day? } \\
\text { b. If not, why } \\
\text { not do it? }\end{array}$ & $\begin{array}{l}\text { frequency is. } \\
\text { - } 10 \text { times a day } \\
\text { - Yeah, washing hands } \\
\text { every day but } \\
\text { determine the } \\
\text { frequency }\end{array}$ & & & & \\
\hline $\begin{array}{l}\text { 2. If you wash your } \\
\text { hands with soap, } \\
\text { what type of soap do } \\
\text { you use (bar/liquid)? }\end{array}$ & $\begin{array}{l}\text { liquid soap } \\
\text {-use wearing liquid } \\
\text { soap } \\
\text { - Liquid Soap } \\
\text { Liquid-sabun }\end{array}$ & Liquid Soap & $\begin{array}{l}\text { Relative } \\
\text { expensive } \\
\text { than } \\
\text { soap } \\
\text { bar }\end{array}$ & $\begin{array}{l}\text { Behavior } \\
\text { CTPS }\end{array}$ & \\
\hline $\begin{array}{l}\text { 3. We are brothers/ } \\
\text { sisters tell me how to } \\
\text { wash your hands } \\
\text { right? Are brothers/ } \\
\text { sisters to practice it? }\end{array}$ & $\begin{array}{l}\text {-Wash your hands } \\
\text { properly -Just shake } \\
\text { and shake } \\
\text { - Can use } 7 \text { steps to } \\
\text { wash your hands - Yes, } \\
\text { you can practice it }\end{array}$ & $\begin{array}{l}\text { Most of them } \\
\text { can practice it }\end{array}$ & $\begin{array}{l}\text { Already } \\
\text { understand }\end{array}$ & $\begin{array}{l}\text { CTPS } \\
\text { knowledge }\end{array}$ & \\
\hline $\begin{array}{l}\text { 4. In your opinion, } \\
\text { do you think } \\
\text { washing hands with } \\
\text { soap can reduce it }\end{array}$ & $\begin{array}{l}\text {-Washing hands with } \\
\text { soap can reduce the } \\
\text { risk of transmission of } \\
\text { covid-19 } \\
\text { - Washing hands with } \\
\text { soap reduces } \\
\text { virus transmission }\end{array}$ & $\begin{array}{l}\text { CTPS } \\
\text { reduce } \\
\text { transmission } \\
\text { covid } 19\end{array}$ & convinced & $\begin{array}{l}\text { Knowledg } \\
\text { e CTPS }\end{array}$ & \\
\hline
\end{tabular}




\begin{tabular}{llccc}
\hline Topic & Code & $\begin{array}{c}\text { Sub } \\
\text { category }\end{array}$ & Category Unit & Theme \\
\hline
\end{tabular}

risk of contracting the virus covid-19?
a. If yes, why?
b. If not, why?

covid and make the

virus die

- Yes, it can reduce the risk of transmission because hands are used to hold anything and we don't know whether our hands are hygienic or not.

-Yes, it could be because of the hands of one place that holds a lot of germs

\section{We are brothers/} sisters tell me whether that is felt by brother/ sister before and after handwashing with soap future of this pandemic? -there is a difference before and after washing hands with soap

-there is a difference before and after washing hands with soap

- before washing hands worrying and after washing hands feeling safe

- Before washing hands feeling worried, afterward felt calm and safe.

$\begin{array}{lll}\text { experiencing } & \text { Feeling } & \text { behavior } \\ \text { differences } & \text { safer after } & \text { CTPS } \\ \begin{array}{l}\text { before and after } \\ \text { washing hands } \\ \text { with soap }\end{array} & \text { washing } & \\ & \text { hands } & \end{array}$

6. In your opinion, how important is it to wash your hands with soap during the COVID-19 pandemic? -washing hands with soap becomes important

- Handwashing is very important to avoid the covid virus, other viruses, and bacteria

- is important

-very important

$\begin{array}{lll}\text { Considered very } & \text { very } & \text { knowledge } \\ \text { important days } & & \text { CTPS } \\ \text { of the pandemic } & \text { important } & \\ \text { is } & \end{array}$




\begin{tabular}{l} 
Topic \\
\hline 7. What does the \\
brother/sister of the \\
person Anyone else \\
who underestimates \\
washing their hands \\
with soap during this \\
pandemic?
\end{tabular}

- Very regretful if there are people who don't wash their hands
- Upset with people who ignore simple things like this ple

- Often feel annoyed.

-feeling annoyed to see other people who underestimated washing their hands with soap .

s

Feeling annoyed with people who

underestimate

handwashing.

Code

Sub category

Point of

view

towards

other

people.
Category Theme

Attitudes

related to

CTPS
8. What actions will you take when you see people who don't wash their hands in public or even at home?
-When someone visits my house, I usually

tell them to wash their hands before entering my house

- $\quad$ Remind and reprimand if they see people outside the house not washing their hands

- Approach people

- Reprimand them if they visit the house.

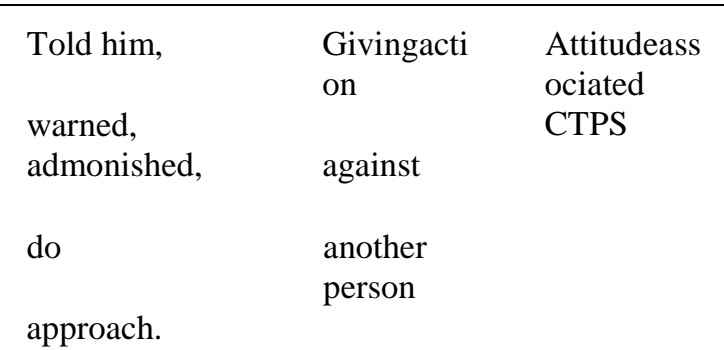

\section{Told him,}

warned, admonished,

do

approach.

$\begin{array}{ll}\text { Givingacti } & \begin{array}{l}\text { Attitudeass } \\ \text { ociated } \\ \text { on }\end{array} \\ \text { CTPS }\end{array}$

against

another

person

\section{How does anxiety or worry brothers/sisters when not wash their hands thoroughly and correctly during this pandemic?}

\section{- I just feel anxious and suggest if I haven't washed my hands and my hands feel sticky if I haven't washed my hands}
- Afraid of being exposed to the covid virus and other diseases
- Very worried because my hands can hold anything and the fast transmission of Covid- 19

$\begin{array}{lll}\text { Feeling anxious } & \text { Point of } & \begin{array}{l}\text { Attitudes } \\ \text { and worried }\end{array} \\ \text { when not doing } & \text { view } & \text { CTPS } \\ \text { CTPS } & & \end{array}$




\begin{tabular}{ccccc}
\hline Topic & Code & $\begin{array}{c}\text { Sub } \\
\text { category }\end{array}$ & Category Unit & Theme \\
\hline
\end{tabular}

- Very worried

10. Can you tell me whether there are any barriers to hand washing when you are in public?
-There are no barriers to doing ctps

- Barriers in public places used soap are not refilled and broken faucets are not immediately corrected

- There are no obstacles for now

- Barriers found are usually about running out of water and soap.

$\begin{array}{lll}\begin{array}{l}\text { Some are still } \\ \text { experiencing }\end{array} & \text { Barriers to } & \begin{array}{l}\text { Attitudes } \\ \text { related to } \\ \text { CTPS }\end{array}\end{array}$

obstacles.

in

public
11. How do you deal with obstacles? especially covid during a pandemic?
In public places such

-If no handwashing facilities usually provide hand sanitizer to clean my hands

- Always carry hand sanitizer

- There are no obstacles for now, at least bring hand gel

- Often bring your cleaning tools such as hand sanitizer or wet tissue.

$\begin{array}{lll}\text { Using } & \text { Relative } & \text { Related } \\ & & \text { AttitudesC } \\ \text { handsanitizer } & \text { affordable } & \text { TPS }\end{array}$

12. Tell us whether you often share stories about how important it is to wash your hands during a pandemic
- Often exchanges information with others

- Likes to tell stories to friends and family Often talks about the
Often do and exchange stories with others

Take action

Attitudes

\section{CTPS}




\begin{tabular}{|c|c|c|c|c|c|}
\hline Topic & Meaning Unit & Code & $\begin{array}{c}\text { Sub } \\
\text { category }\end{array}$ & Category & Theme \\
\hline $\begin{array}{l}\text { with your family, } \\
\text { other people, or } \\
\text { anyone else? }\end{array}$ & $\begin{array}{l}\text { importance of washing } \\
\text { hands with soap } \\
\text { - Usually exchanging } \\
\text { stories is only limited } \\
\text { to family. }\end{array}$ & & & & \\
\hline $\begin{array}{l}\text { 13. Who advises or } \\
\text { tells brothers/sisters } \\
\text { about the } \\
\text { importance } \\
\text { washing of } \\
\text { during hands } \\
\text { pandemic? }\end{array}$ & $\begin{array}{l}\text {-I'm aware of it myself } \\
\text { - A friend advised me } \\
\text { to wash my hands } \\
\text { - Government advice } \\
\text { and several notice } \\
\text { boards wherever you } \\
\text { are } \\
\text { - At first, watching the } \\
\text { news and looking for } \\
\text { information, over time } \\
\text { I got used to it. }\end{array}$ & $\begin{array}{l}\text { Self-awareness, } \\
\text { friends, } \\
\text { recommendatio } \\
\text { ns } \\
\text { government, } \\
\text { and news }\end{array}$ & $\begin{array}{l}\text { Awareness } \\
\text { of } \\
\text { CTPS }\end{array}$ & $\begin{array}{l}\text { Attitudes } \\
\text { related to } \\
\text { CTPS }\end{array}$ & \\
\hline
\end{tabular}

The intensity for washing hands per day is different for each respondent, some are erratic and some answer more than 10 times. Based on questions related to the type of soap used by the informants when washing their hands, the four respondents answered that they used liquid soap to wash their hands with soap. And for the last behavioral variable, namely the differences experienced by the informants before washing their hands and before washing their hands, the four informants answered that there was a difference if they did not wash their hands with soap, plus the presence of the covid 19 virus made respondents feel afraid. For attitude variables related to CTPS, namely, the views of informants regarding people who underestimate hand washing during a pandemic, from 4 respondents who were interviewed that they felt annoyed and angry if there were still people who were still negligent and did not want to wash their hands with soap. Anxiety and worry often occur in informants when they do not wash their hands with soap. Of the 4 respondents interviewed, most of them often feel anxious and worried when they do not do CTPS because they feel they are afraid of the virus sticking to their limbs.

Based on questions related to the obstacles they experienced when washing their hands with soap during the pandemic, from the 4 respondents interviewed, 2 informants admitted that there were obstacles in washing hands when in public places. The obstacles she faced were soap that was running out and not being refilled, broken faucets, and inadequate handwashing. The solution for the four informants when there were obstacles during the pandemic to carry out CTPS for the respondents 
was to use hand sanitizer as a substitute for CTPS.

Regarding the importance of CTPS during the Covid-19 pandemic, the four respondents already knew about the importance of CTPS during the pandemic. Informants admitted that they knew about it through various media, for example, electronic media, news that had appeared on television, social media, and other print media. Information is now very easy to obtain. However, information that is easily obtained must be filtered very wisely so as not to be consumed by hoax news.

Based on the variable knowledge about CTPS, the four informants were classified as quite knowledgeable. Questions related to how to wash hands properly and correctly, most of the four respondents did not know in detail the recommended hand washing steps.

Handbehavior with soap (CTPS) in this study includes hand washing intensity. during the pandemic, the type of soap used, and also the differences experienced before and after washing hands. The results showed that the informants washed their hands during the pandemic with erratic intensity depending on their needs. "Yes, I wash my hands with soap every day. I don't know how many times, depending on the need, basically every time I come from outside the house or if my hands are dirty, I wash my hands." $(R)$. and some already know it and can also practice it properly. The four informants also know that hand washing during this pandemic is very important, especially in terms of preventing the transmission of the coronavirus which is endemic in this world.

According to research, regular hand washing more than 6 times a day can reduce the risk of contracting the Covid-19 coronavirus by up to a third more effectively. Experts from University College London say their study has shown that rubbing hands can help kill killer germs or deadly viruses. The research team analyzed disease data from 1,633 people in the UK over 3 winters. The participants always reported on the routine of their hands and the scientists identified a cold infection triggered by the coronavirus. As a result, they found regular hand washing between 6 and 10 times a day could help reduce the risk of infection by 36 percent compared to people who rarely wash their hands. Washing our hands.

regularly can help us keep the virus infection rate low and reduce the risk of transmission.

From the four informants, the average type of soap used was the same, namely the type of liquid soap "I always use the liquid one, Sis because I always use the liquid at home and when I leave the house I always provide the liquid one too" (DA). Cleaning hands with water and soap, the level of efficacy in removing bacteria on hands can be different, in this case, if only washed with water, only a few bacteria will come out, while soap can remove a lot of bacteria because in soap there are special ingredients that can control the bacteria present in the hands. In this case, there are several active ingredients contained in hand soap, namely alcohol, emollient, triclocarban, triclosan, triclocarban, and others (Nakoe, Ayini S, \& Mohamad, 2020).

The use of soap for washing hands is more due to dirty reasons only. Most people also view 
that soap is only useful for removing dirt and odors, when in fact soap itself has many benefits, including killing and reduce bacteria or germs that may enter the body. Using antiseptic liquid soap is more effective than hand sanitizer, so the use of antiseptic liquid soap is more recommended than hand sanitizer (Fauztihana, Khudayani, \& Qomarkan, 2020).

The perceived difference of four respondents regarding the impact of the before and after handwashing with soap that is, when before washing hands frightened by anything that sticks in his hands, feeling sticky, feel less, and if it did it very quietly because it feels cleaner "If before the person has a sense of misgivings, like he is worried that there are germs or anything in his hands, right after he feels safer and more comfortable to do anything because the inner feeling feels calm by washing his hands" (AS).

The purpose of handwashing is to mechanically remove dirt and dust from the skin surface and reduce the number of microorganisms. Washing hands with soap is an easy and inexpensive way to clean body parts, especially hands from infectious germs (Azam, Sumardiyono, \& Murti, 2016).

Attitudes related to Hand Washing with Soap (CTPS) in this study include the views of informants related to people neglecting hand washing, worrying if they do not wash their hands, actions of people who do not wash their hands when visiting, obstacles in washing hands, solutions to these obstacles, and share experiences related to CTPS.

From the perspective of the four informants regarding people who underestimate hand washing during this pandemic, on average they feel very upset if until now they have not washed their hands with soap "Oops, I feel annoyed myself because that's one way to prevent transmission but there are still people who underestimate like this, this is important but why is it still not running" $(U S)$. In addition, all informants revealed that they were worried if they did not wash their hands, apart from being afraid of contracting the coronavirus, they were also afraid of contracting other diseases. "Besides being afraid of being exposed to the current virus, I am also afraid that if I do not wash my hands thoroughly, I will get other diseases" (DA ). In carrying out any activity, of course, there are obstacles. In this study, the four informants, 2 of whom said there were no obstacles in washing hands with soap during this pandemic and 2 others said that there were obstacles in doing this CTPS, namely in terms of facilities and infrastructure. Sometimes it's lazy in public, the soap runs out, or the water, so I just use a hand sanitizer. Sometimes the water or soap container is not clean, so it makes me lazy to wash my hands." (R). Currently, many initiatives from various institutions, organizations, and companies have provided CTPS facilities in public places with various operational and maintenance procedures. Therefore, this practical guide has been prepared to serve as a reference for stakeholders and the government to prevent the spread of COVID-19 through promoting the practice of washing hands with soap and providing proper handwashing facilities with soap in various places. Stakeholders can include the government, development partners, NGOs, universities, the private sector, business 
people, social organizations, and communities (Kemenkes RI, 2020). The attitude becomes a predisposing factor to do or not to do a certain behavior, attitude becomes an individual awareness process. This means that this process occurs in the individual subjectively and uniquely. The attitude of the community towards handwashing can affect whether or not the carried behavior of washing hands out by the community. The more positive a person's attitude is, the more likely the action will occur. Broadly speaking, the attitudes of the four informants were classified as good, this would trigger actions or handwashing behavior. Washing hands is one way to prevent disease, through a good attitude it is hoped that the incidence of illness that occurs in the community can decrease (Lestari, 2016).

Attitude measurement can be done by assessing a person's attitude statement, which is a series of sentences that say something about the attitude object to be revealed. Attitude statements can contain or say positive things about the object of attitude, namely the sentence has the nature to support or favor the object of attitude which is called a favorable statement. Meanwhile, attitude statements that contain negative things about the attitude object, namely those whose sentences are neither unfavorable

supportive nor contra towards the attitude object are called statements. Attitude measurement can be done either directly or indirectly. If it is done directly, it can be asked how the respondent's opinion or statement is about an object. Meanwhile, indirect attitude measurement can be done with hypothetical statements, and then the respondents' opinions are asked through a questionnaire (Mawarni, 2013).

Knowledge related to Hand Washing with Soap (CTPS) in this study included the importance of CTPS, proper and proper handwashing, prevention of transmission of the Covid-19 virus by washing hands. The results of research related to the knowledge of the importance of washing hands from the four informants revealed that hand washing is very important during this pandemic. "I think during the covid-19 pandemic like this washing hands is very important, actually before the pandemic washing hands is also important because washing hands can protect us from bacteria or viruses" (IIS).

Knowledge of informants related to the flow or how to wash hands is good and right, not all of them are true or know it. One of the informants thought that washing hands was just by shaking the water in the container. "Well, at least I wash my hands, I just shake it like that" (DA). However, one of the informants (AS) already understands and can practice good and correct hand washing "Can the rich first wash their hands with water, take enough soap, rub both palms then between days then the back of the hand, then rotate the thumb and finally, it's like twirling my fingers in my palm and then rinsing it off, it's like when I wash my hands" (AS). Knowledge plays an important role in the occurrence of voluntary behavior, which arises from awareness. Knowledge is the forerunner of 
beliefs (cognitive aspects of attitudes) and attitudes. Knowledge of critical time is included in the knowledge to behave and is part of the behavioral capability variable in Social Cognitive Theory. Knowledge of the concept of cause and effect is not sufficient to behave. A person is unlikely to carry out a behavior if he does not know "what the behavior looks like", "behavioral steps" "when the behavior must be carried out", "where the behavior can be carried out" and "where the object of the behavior can be obtained" Measurement of knowledge about The behavior of washing hands with soap includes knowledge about the meaning of washing hands with soap, the benefits of washing hands with soap, diseases that can occur if you don't wash your hands with soap when it's important to wash your hands with soap, and how to wash your hands with soap properly (Mustikawati, 2010). 2017). Most of the informants did not understand the steps for good and correct hand washing. WHO (2009) has determined the steps for washing hands with soap as follows: wetting both hands with running water, giving enough soap, rubbing the palms of the hands and the backs of the hands, rubbing between the fingers of both hands, rubbing the palms with the fingers tightly, the fingers are brought together while rubbing into the palm, the left hand to the right, and vice versa, rubbing the thumb in a circular motion in the grip of the right hand, and vice versa, rubbing the nail of the right finger in a circular motion to the palm of the left hand, and vice versa, wash with water and drying hands (WHO, 2009).

Based on the results of Azam et al's research (2016) regarding the relationship between students' knowledge level and handwashing behavior with soap $(\mathrm{p}<0.001)$ there is a significant relationship, and it is known that students with high knowledge have the possibility of washing their hands with soap by $22(\mathrm{OR}=22.06)$ times greater than students with low knowledge. Students with high knowledge have a greater possibility to wash their hands with soap, namely $86.3 \%$ compared to those with low knowledge of washing hands with soap, which is $22.1 \%$ (Azam, Sumardiyono, \& Murti, 2016).

Other research results related to preventing the transmission of covid-19 by washing hands with soap, three informants already knew about it and believed that washing hands can prevent transmission of covid-19 "Yes, I think washing hands with soap can reduce the risk of transmission of covid-19 because it may be in the womb. the soap can kill germs or bacteria" (IIS) and 1 other feel less sure that washing hands can prevent the transmission of covid-19'm "It could be like that... but I not sure too because the spread of the covid virus is increasing, I'm not sure, it can where have you been... But washing your hands is a must during a pandemic because your hands must have a lot of germs or viruses..." $(R)$.

The Covid-19 pandemic in Indonesia has been running for almost 1.5 years. Transmission of COVID-19 is a disease caused by the SARS CoV-2 virus which is part of the Coronavirus type. This virus can be transmitted if we come into direct contact with an infected person or with the fluids 
released by coughing and sneezing. Viruses can be transferred to our bodies if we accidentally touch these objects and then touch our face (eyes, mouth, and nose) with contaminated hands. Washing your hands frequently and appropriately (for at least 40 seconds) is one of the most important steps to prevent COVID-19 infection. CTPS is much more effective at killing germs, bacteria, and viruses than washing hands with water alone. Soap can easily destroy the lipid membrane of COVID-19, rendering the COVID-19 virus inactive (Kemenkes RI, 2020).

\section{CONCLUSION AND SUGGESTIONS}

This virus can be easily prevented by washing hands with soap (CTPS). Handwashing with soap is a process that mechanically removes dirt and debris from the skin of the hands by using soap (either containing antimicrobial or non-antimicrobial) and water. Washing hands with soap is an easy, cheap, and simple healthy behavior that can scientifically prevent the spread of infectious diseases. Washing your hands with soap during this pandemic is influenced by behavior, attitudes, and knowledge.

According to the results of the study, the four informants had carried out handwashing behavior with soap during this pandemic. Broadly speaking, the attitudes of the four informants were classified as good, this would trigger the emergence of actions or handwashing behavior. The knowledge of the four informants based on the research is still there, most of them do not know how to wash hands properly and correctly. According to the results of research on members of each researcher in South Tangerang City regarding handwashing with soap during the pandemic, they have considered it very important and knew the impact if they did not do it.

The government should prepare all adequate facilities and infrastructure so that handwashing activities with soap during this pandemic can run optimally.

For researchers to be able to continue their more in-depth research related to the description of PHBS behavior with CTPS during the Pandemic and can be studied further.

\section{REFERENCES}

1. Azam, AM, Sumardiyono, \& Murti, B. (2016). Hubungan Tingkat Pengetahuan, Sikap terhadap Perilaku Cuci Tangan Pakai Sabun (CTPS) Pada SMPN 1 Surakarta dan SMPN 6 Surakarta.

2. Badan Penelitian, d. P. (2013). Riset Kesehatan Dasar. Jakarta: Kementrian Kesehatan RI.

3. Covid-, DSP et al. (2020) 'NI PUTU UDAYANA ANTARI. Jurnal Ilmiah Medicamento Vol 6(2), 94-99', Jurnal Ilmiah Medicamento, 6(2), pp. 94-99.

4. Dinas Kesehatan, PB (2020). Profil Kesehatan Provinsi Banten.

5. Fauztihana, I., Khudayani, R., \& Qomarkan, M. (2020). Keefektifan Penggunaan Hand Sanitizer sebagai Pengganti Sabun dan Air dalam Cuci Tangan Selama Pandemi Covid-19.

6. Hadi, S. (2010) 'Pemeriksaan Keabsahan Data Penelitian Kualitatif Pada Skripsi', pp. 21-22 
7. Hardiningrum, Hakim, Z. (2021) 'Early Childhood: Jurnal Pendidikan MASA PANDEMI COVID-19', 5(1).

8. Haryani, S. (2021). Pengetahuan dan Perilaku Mencuci Tangan Pakai pada Siswa SWMK Sebagai Upaya Pencegahan Covid-19. Jurnal Keperawatan dan Kesehatan Masyarakat, 10(1):85-91.

9. Kemenkes RI. (2020). Panduan Cuci Tangan Pakai Sabun. Jakarta.

10. Lestari, AO (2016). Hubungan Pengetahuan dan Sikap Terhadap Perilaku Cuci Tangan pada Masyarakat Kelurahan Perigian. Jurnal Promkes, 1-11.

11. Mawarni, Y. (2013). Hubungan Tingkat Pengetahuan, Sikap dan Perilaku Cuci Tangan Pakai Sabun (CTPS) pada Ibu-Ibu yang Memiliki Balita di Dukuh Merbung Kulon dan Dukuh Merbung, Desa Merbung, Kecamatan Klaten Selatan, Kabupaten Klaten. Karya Tulis Ilmiah.

12. Muliadi, \& Sari, I. (2015). Pengetahuan, Sikap, dan Perilaku Cuci Tangan Pakai Sabun pada Mahasiswa FKIK UIN Syarif Hidayatullah Jakarta. In Skripsi. Jakarta. 